\title{
Facies analysis of the Codó Formation (Late Aptian) in the Grajaú Area, Southern São Luís-Grajaú Basin
}

\author{
DILCE F. ROSSETTI ${ }^{1}$, JACKSON D.S. PAZ ${ }^{2}$ and ANA M. GÓES ${ }^{2}$ \\ ${ }^{1}$ Museu Paraense Emílio Goeldi, Coordenação de Pesquisa e Pós-Graduação \\ Cx. Postal 399, Av. Perimetral, 1901, Terra Firme, 66077-530 Belém, PA, Brasil \\ ${ }^{2}$ Universidade Federal do Pará, Centro de Geociências, Campus do Guamá s/n, \\ 66075-900 Belém, PA, Brasil \\ Manuscript received on September 26, 2003; accepted for publication on February 19, 2004; \\ presented by ALCIDES N. SIAL
}

\begin{abstract}
Facies descriptions of the Codó Formation in the Grajaú area are provided for the first time, and its sedimentary characteristics compared to those from the Codó area to allow paleoenvironmental reconstructions. Deposits in the Grajaú area include evaporites, limestones and argillites bearing features indicative of a shallow, low energy, subaqueous, saline environment exposed to meteoric and/or capillary conditions. Floodingevaporative concentration-desiccation cycles suggest a saline pan complex surrounded by extensive evaporitic mudflats. The location of the system, whether coastal or inland, is a matter open for debate. However, the later hypothesis is favored considering: 1. Sr isotopic data, with values higher than those expected for Late Aptian marine waters; 2. calcitic composition of limestones (instead of dolomitic and/or magnesitic as expected in coastal settings); and 3. presence of continental ostracods and lack of marine fauna. This interpretation is consistent with that proposed for Upper Aptian deposits of the Codó area, but the depositional system there was one dominated by more stable, well-stratified, anoxic waters and evaporite precipitation in central lacustrine areas, while in the Grajaú area the salt pan was more oxygenated and ephemeral, with salt precipitation mainly in marginal areas or along surrounding mudflats.
\end{abstract}

Key words: evaporite, paleoenvironment reconstruction, lacustrine, Late Aptian, facies analysis, São LuísGrajaú Basin.

\section{INTRODUCTION}

The Codó Formation was deposited during an important moment in the evolution of the Brazilian Equatorial Margin, representing the only exposed record of the Late Aptian early rifting stage. Despite its great scientific relevance for reconstructing Cretaceous events in South America, this unit has been only locally studied. Upper Aptian deposits occur in subsurface throughout the São Luís-Grajaú

Correspondence to: Dilce de Fátima Rossetti

E-mail: rossetti@dsr.inpe.br
Basin, but outcrops exist only in its eastern and southern margins. Facies and stratigraphy of strata exposed in the eastern margin of this basin were emphasized in recent publications (e.g., Paz and Rossetti 2001, Rossetti et al. 2001). However, this type of study is completely lacking with respect to the rocks that occur in the southern edge of the basin. The Codó Formation is well exposed in the Grajaú area (Fig. 1A), where it consists of deposits lithologically similar to those from the Codó area, being represented by evaporites, laminated argillites, 
black shales and limestones. In addition, a preliminary study revealed facies in the Grajaú area that have not been documented for the Codó Formation in the Codó area yet. The evaporite succession from the Grajaú area is better developed and shows a set of well-preserved primary sedimentary features not recorded in association with evaporites from the Codó area, and which are very helpful to improve the characterization of the depositional system proposed for this unit. Exposures in the Codó area display a dominant lacustrine nature, marked by several episodes of progradation recorded by upward cycles with gradation from central to intermediate and then marginal lacustrine deposits formed in a dominantly hypersaline and stratified system with a closed hydrology time to time (Paz and Rossetti 2001). Sr and $\mathrm{S}$ isotope data support the existence of continental deposits in this area (Rossetti et al. 2000, Paz et al. 2003). The exposures of the Grajaú area are important to analyze the possible continuity of the lake system southwestward in the basin, and precise when a full oceanic connection developed for the first time along the Brazilian Equatorial Margin.

\section{GEOLOGICAL FRAMEWORK}

The São Luís-Grajaú Basin occupies an extensive area in the Brazilian Equatorial Margin, and is included in the Gurupi Graben System (Azevedo 1991), formed by simple shear and strike-slip motions associated with the opening of the Equatorial Atlantic Ocean during the Early Cretaceous. Subsurface and surface data show that faulting was important particularly during the Early/Middle Albian, when the sedimentary successions throughout this basin experienced the greatest offsets (Góes and Rossetti 2001). The rift system became abandoned, resulting in an aborted intracontinental feature as the continental break up migrated northward. The sedimentary filling of the São Luís-Grajaú Basin (Fig. 1B) reaches up to 4,000 $\mathrm{m}$ thick in the depocenters, and consists chiefly of Cretaceous deposits organized into three depositional sequences (S1, S2 and S3) formed during the Late Aptian/Early Al- bian, Early-Middle Albian/ and Middle Albian/Late Cretaceous, respectively (Rossetti 2001). The lowermost sequence $\mathrm{S} 1$ contains the Codó Formation, which is the objective of this paper, and represents a succession up to $450 \mathrm{~m}$ thick of sandstones, evaporites, shales and limestones. This sequence displays a tripartite subdivision into systems tracts (Rossetti 2001), with the lowstand deposits grading southward progressively from shallow marine to continental (i.e., fluvial, deltaic, and lacustrine). The lowstand deposits are overlain by strata formed in the transgressive systems tract, and consist of a wedge of richly fossiliferous shales that pinches out to the south. The highstand systems tract consists of shallow marine to continental deposits displaying stratal patterns varying upward from aggradational to progradational, as typical for this stage of sequence development.

The maximum thickness of the Codó Formation in the Grajaú Basin is $150 \mathrm{~m}$ (Rezende and Pamplona 1970). Its paleontological content mostly includes pollen, continental ostracod, insect, and fish, which are all in agreement with a dominantly lacustrine interpretation for the depositional system. Additionally, pollen has been recovered from these deposits and allowed the establishment of a precise Late Aptian age with basis on the presence of Sergipea variverrucata (Batista 1992, Lima 1982, Rossetti et al. 2001). The Codó Formation either grades downward into fluvial and deltaic deposits of the Grajaú Formation (e.g., Mesner and Wooldridge 1964, Aguiar 1971, Lima and Leite 1978) or sharply overlies an unconformity over older Paleozoic and Triassic basement rocks (Aguiar 1971). Its upper contact is an unconformity with Albian to Cenomanian shallow marine, green to brownish-red mudstones interbedded with fine- to very fine-grained, cross-stratified sandstones of the Itapecuru Group (e.g., Rossetti and Truckenbrodt 1997, Rossetti et al. 2001).

Surface studies in the Codó area led to the recognition of three lacustrine facies associations in the Codó Formation, which are arranged, according to Paz and Rossetti (2001), into shallowing-upward 


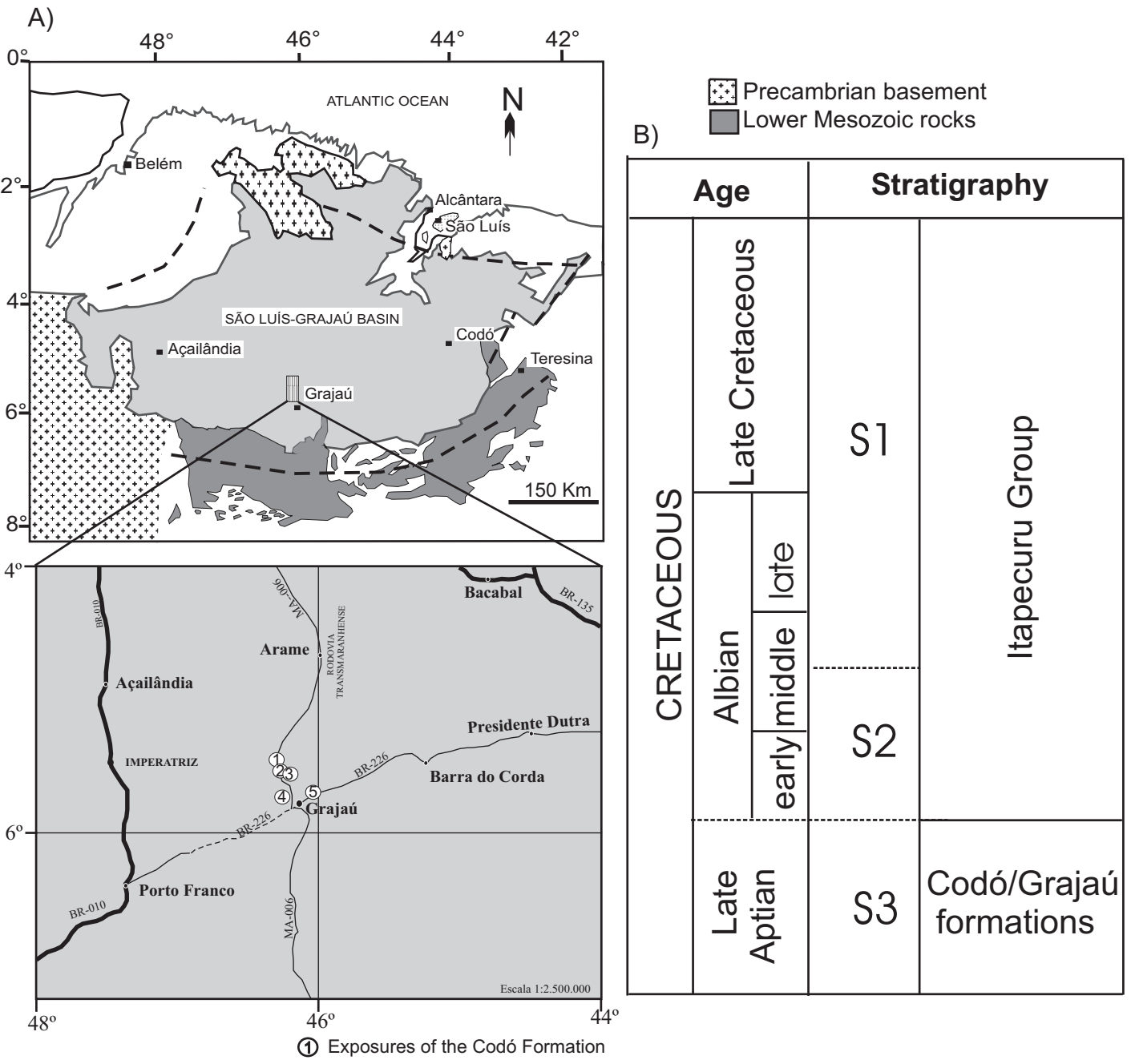

Fig. 1 - A) Location map of the Grajaú area in the south of the São Luís-Grajaú Basin, where the studied exposures of the Codó Formation are located. B) Simplified stratigraphy of the São Luís-Grajaú Basin (after Rossetti 2001).

cycles attributed to: 1 . central lake deposits, consisting of black bituminous shale and evaporite formed at the base of the cycles; 2. intermediate deposits, representing laminated argillite, lime-mudstone, peloidal mudstone to packstone, and meso-crystalline limestone; and 3. marginal lake deposits, consisting of a variety of shallow water to subaerially exposed facies including massive pelite with pedogenetic features, fenestral calcarenite, ostracodal wackestone to packstone, pisoidal packstone, gipsarenite, tufa, rhythmite of limestone, argillite, and microbial mat.

\section{SEDIMENTARY FACIES}

The Codó Formation is exposed along several open mines in the Grajaú area that average $15 \mathrm{~m}$ thick and are currently under exploration for gypsum. At some localities, the Codó Formation is in sharp contact (sometimes by faulting) with underlying basalts of the Parnaíba Basin. Despite the long distance (i.e., more than $250 \mathrm{~km}$ ), these deposits show many aspects that are similar to the Aptian deposits exposed in the Codó area: a) the lithologies are dominated by evaporite, limestone, black shale and argillite; b) 
TABLE I

Synthesis of facies characteristics of the Codó Formation in the Grajaú area.

\begin{tabular}{l|ll|l}
\hline & \multicolumn{2}{|c|}{ Facies description } & Interpretation of depositional setting \\
\hline Evaporite & Gl & Laminated gypsum & Shallow, subaqueous, ephemeral deposition in \\
& Gm & Massive/macronodular gypsum & marginal saline pans and mud flats \\
& Gy & Gypsarenite & \\
\hline Limestone & Mm & Massive mudstone & Low energy, shallow subaqueous environments \\
& Mpl & Laminated mudstone-packstone & distant from a significant terrigenous inflow and with \\
& $\mathrm{T}$ & Tufa & periodic subaerial exposure. Considering the proposed \\
& $\mathrm{Bls}$ & Stromatolitic, laminated boundstone & depositional system, these deposits formed probably \\
& $\mathrm{B}$ & Breccia & in the margins of saline pans and mud flats. \\
\hline \multirow{2}{*}{ Argillite } & Al & Laminated argillite & Deposition from suspension in low energy, \\
& Am & Massive argillite & subaqueous salt pans and mud flats. \\
& Sb & Black shale & \\
\hline
\end{tabular}

the unit is also overlain by Albian deposits of the Itapecuru Group, here represented exclusively by well-stratified sandstones and argillites formed in a wave-dominated deltaic system (Rossetti and Góes 2004); c) though less intense, the deposits display evidences of soft sediment deformation; and d) facies are organized into several shallowing-upward cycles, as described below.

Several facies characterize the Codó Formation in the Grajaú area, which will be grouped into three lithological components for descriptive purposes as evaporites, limestones and argillites (Table I).

\section{EVAPORITES}

Description. Evaporites are particularly well developed in the Grajaú area, representing laterally continuous deposits that reach up to $5 \mathrm{~m}$ thick. Thin layers of laminated argillites and/or limestones occur within the evaporites, defining cycles that are up to $3 \mathrm{~m}$ thick (Fig. 2). As opposed to the Codó area, where shales and limestones are the main lithologies, evaporites represent the main deposits in the studied sections, consisting of three facies: 1. laminated gypsum (facies Gl); 2. massive/macronodular gypsum (facies Gm); and 3. gypsarenite (facies Gy).
Laminated gypsum (facies Gl) is the dominant facies (Fig. 3A) and consists of parallel laminated beds typically formed by alternating darker and lighter couplets that become progressively thicker upward (Fig. 3B), varying from a few mm up to $15 \mathrm{~cm}$ thick. The darker beds consist of either crystals or micronodules of gypsum, in general less than $0.5 \mathrm{~cm}$ long, distributed within a matrix of black shales (Fig. 3D). Petrographic analysis reveals that the nodules might be locally replaced by a mosaic of gypsum crystals with sutured contacts, which grew beyond the boundaries of individual nodules. In these cases, the micronodular texture might be recognized by the presence of clays surrounding the nodules. The lighter gypsum consists of upwardoriented fibrous crystals displaying aligned twin planes and superimposed growth faces with acute angles arranged as a zigzag, perpendicularly to the crystal long axes (i.e., palmate gypsum; Fig. 3D). Under the microscope, palmate gypsum intergrades with acicular gypsum. In this case, the later displays relics and/or ghosts of the palmate gypsum (Fig. 3E). The darker and lighter couplets of gypsum are organized into packages up to $30 \mathrm{~cm}$ thick, which are marked at the top by a thicker lighter bed, 
(5)

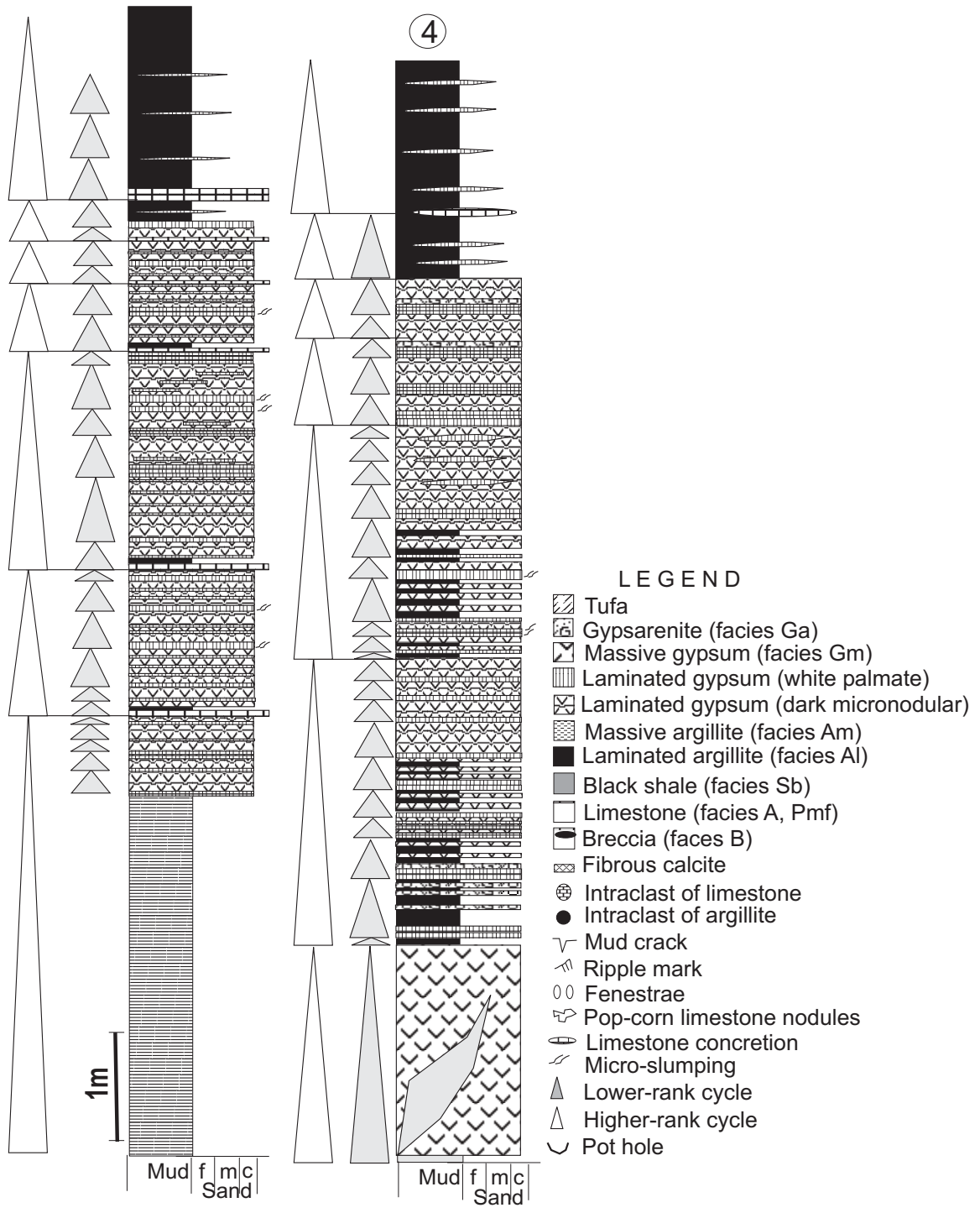

Fig. 2 - Lithostratigraphic profiles representing the evaporite facies of the Codó Formation in the Grajaú area. (See figure 1 for location).

which might reach up to $10 \mathrm{~cm}$ thick upward in the section, when they are associated with microslumpings. The packages contain 3 to 7 couplets, and a succession of 4/7/5/6/6/7/6 couplets was counted at one place (i.e., locality 4 in Figure 1).

The massive/macrogranular gypsum (facies $\mathrm{Gm}$ ) forms unstructured bodies that either grade or are in sharp contact with the laminated gypsum, locally forming diapirs several meters long (Fig. 4A). The massive gypsum may internally display dispersed areas with laminated gypsum (see arrows in Fig. 4A). No rarely, the massive gypsum intergrades with macrogranular gypsum, which consists of centimeter-sized nodules with both matrix-bear- 

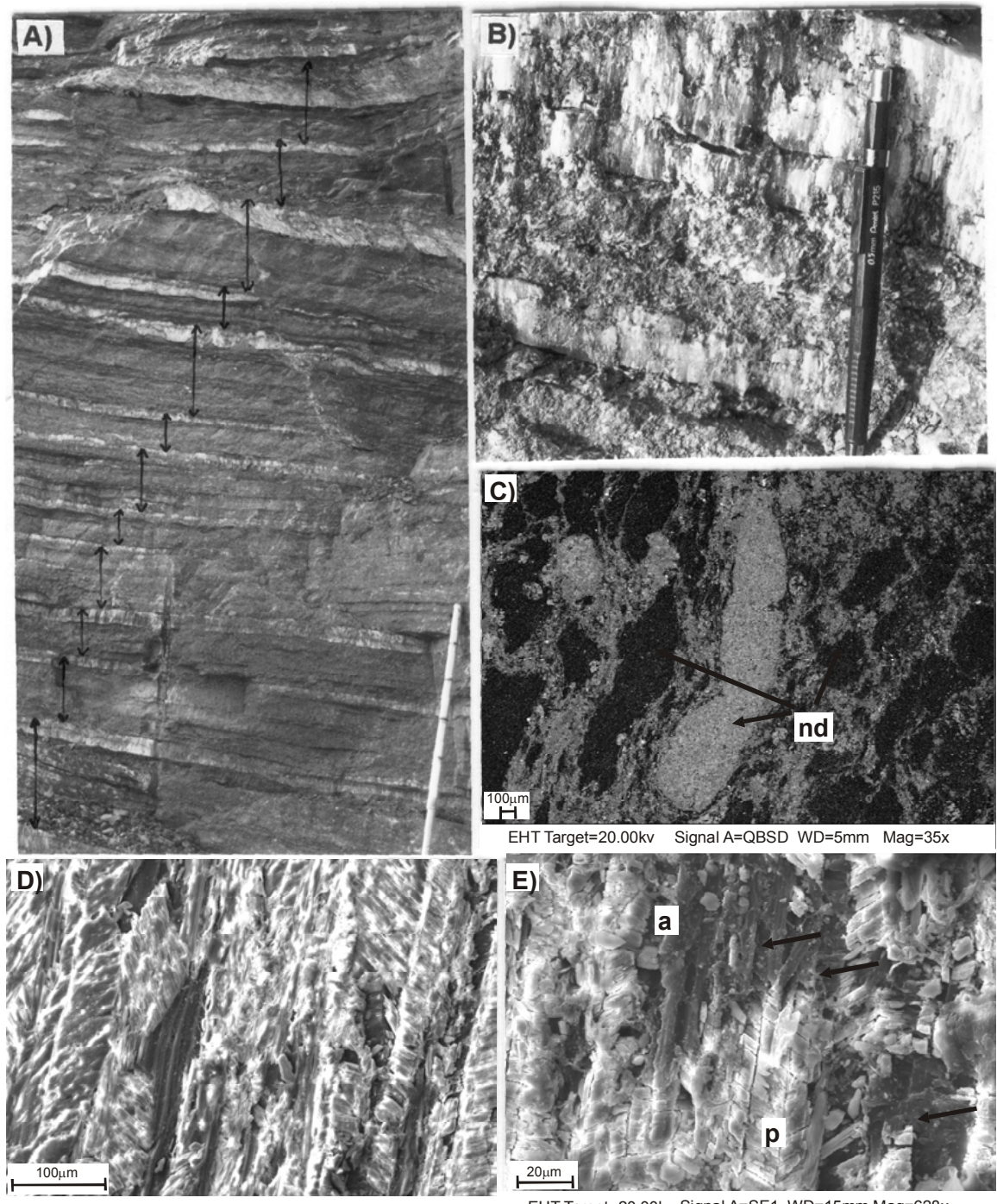

EHT Target $=20.00 \mathrm{kv}$ Signal A=QBSD WD $=5 \mathrm{~mm} \quad$ Mag=35x

EHT Target $=20.00 \mathrm{kv}$ Signal A=SE1 WD $=15 \mathrm{~mm}$ Mag=225x

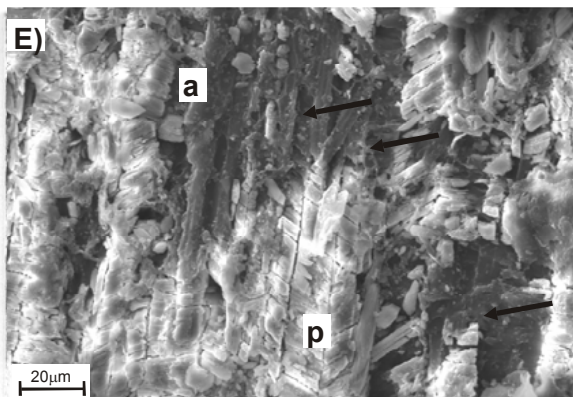

EHT Target $=20.00 \mathrm{kv}$ Signal A=SE1 WD $=15 \mathrm{~mm}$ Mag $=628 \mathrm{x}$

Fig. 3 - Evaporite facies from the Grajaú area, illustrating: A) Laminated gypsum (facies Gl) formed by successive alternating darker and lighter couplets, consisting of micronodular and palmate/acicular gypsum, respectively. Note packages of couplets (arrows) defined by thicker lighter beds, which become progressively thicker upward. (sub-division in the rod for scale $=10 \mathrm{~cm}$ ). B) A detail of a darker/lighter couplet shown in figure A. (pen for scale $=15 \mathrm{~cm}$ long). C-D) Electron microscope photographs showing micronodular gypsum (nd) from a darker part of a couplet (C), palmate gypsum from a lighter bundle of a couplet characterized by growth-aligned crystals with twin planes (D), and palmate gypsum (p) being replaced by acicular (a) gypsum (E). Note in the later the presence of ghosts of the palmate gypsum (arrows) within the acicular gypsum.

ing and matrix-free character. The matrix-bearing texture presents well-defined and rounded nodules with internal saccharoidal, micron-sized gypsum crystals. The matrix-free texture, in turn, is asso- ciated with nodules that are defined by a web of undulated, horizontal to oblique micro-fractures, around which bladed crystals with compromise contact grow. In this case, the nodules display 
an almond-like form.

The gypsarenite facies (facies Gy; Fig. 4B) is interbedded with laminated gypsum, forming layers few $\mathrm{cm}$ thick of moderate to poorly sorted, rounded to sub-rounded gypsum grains with sizes varying from very coarse to pebbly. Calcite cement is common in this facies. Facies Gy increases in frequency towards the top of the evaporite succession, and in this case it might be associated with shallow (i.e., $<2 \mathrm{~m}$ deep) pot holes (Fig. 4C) averaging $3 \mathrm{~cm}$ in diameter and displaying ragged concave up morphologies that are completely filled up by layers of growth-aligned gypsum crystals. Potholes may occur either isolated or as laterally coalescent structures composed by two to 4 holes. A line of yellow to light brownish calciferous clay, mantles the bottom of these structures.

Interpretation. The features observed in the evaporitic deposits indicate precipitation in a very shallow subaqueous environment that was interrupted by periodic exposure. The mineralogy of the evaporites, mostly gypsym, was modified after deposition at certain degree, but as opposed to the Codó area, diagenesis was in general not enough to obliterate the primary structures in the Grajaú area. This is demonstrated by the dominance of gypsum with well-preserved parallel lamination (facies Gl), which reflects original bedding on a flat-lying environment. Deposition was typically cyclic. The 3-m cycles defined by thinly laminated argillites and/or limestones mark periods of salinity and/or depth fluctuations. This conclusion is shown by the successions of numerous alternating lighter and darker couplets, which define higher frequency cycles. The palmate growth-aligned crystals of the lighter beds attest to primary gypsum deposition on the floor of brine pools. Precipitation of similar features in many modern and ancient environments occurs when water depths is less than only $2 \mathrm{~m}$ (e.g., Logan 1987, Handford 1991, Smoot and Lowenstein 1991, Hovorka 1987). Shallow waters favor a high degree of supersaturation, as well as a less dense and unstable brine, which are conditions required to promote the upward growth of crystals. The darker beds in the couplets record displacive intrasediment growth of crystals beneath the brine from supersaturated pore fluids in the capillary and/or upper phreatic zone, thus requesting periods of descending ground waters and eventual exposure (e.g., Kerr and Thomson 1963, Warren 1999). These deposits formed slightly post-depositionally, but still under a strong influence of the depositional setting as precipitation took place within only a few $\mathrm{mm}$ of the depositional surface. Later diagenesis locally resulted in a widespread formation of gypsum beyond the nodules boundaries. The presence of relics and ghosts of palmate gypsum within acicular gypsum in the lighter components of the couplets also reveals a secondary nature for the later, but the effects of diagenesis was rather mild, not disturbing the bedding planes. The sequence of couplets is attributed to pulsating episodes of water table. The growth-aligned crystals grew up in the interface sediment-brine during times when saturated brines were flushed into the basin. The formation of such evaporite layers requires a subaqueous environment with stable phases to allow the aggradation of the upper euhedral surface of the crystals (Warren 1999). As the water level falls, precipitation of this type of crystals is precluded. During these episodes, evaporite precipitation in the study area occurred only below the sediment interface. Although locally observed, packages displaying regularly distributed bundles varying from 4 to 6 probably reflect a seasonal signature. The upward increased thickness of lighter layers with growth-aligned gypsum in these packages reveals a brining up character. As bigger crystals precipitated in the upper portions of the packages, they progressively slid down into underlying muddier deposits due to overloading, resulting in the microslumps observed in the study area.

The gypsarenite records moments when evaporite crystals were reworked. Because these deposits are mostly associated with the laminated gypsum, it is possible that its formation is due to 
reworking of growth-aligned crystals as the water level slightly decreased, but with the process occurring still subaqueously. The increased occurrence of this facies upward in the evaporite section attests to progressive shallowing, which is supported by the presence of numerous pot holes, attributed to partial evaporite dissolution due to subaerial exposure. As the evaporite basin was dissected, the deposits were at least momentously kept above the water level, when dissolution took place, forming these small depressions. The ragged morphology supports dissolution process. Water accumulated in these depressions, bringing suspended sediments, that were settled down forming the clay films. A later submergence of the dissolved planes led to the infill of the pot holes by thin layers of growth-aligned crystals (Fig. 4).

The massive/macrogranular gypsum is attributed to post-depositional salt displacement. As this process took place, the original structures were greatly obliterated, forming a dominantly massive deposit. This conclusion is based on the fact that facies Gm laterally grades into laminated gypsum and internally display relics of this facies. Hence, most of the macronodular gypsum is interpreted as secondary. Definition of macronodules by microfractures suggests nodulation induced by fracturing during halocinesis.

\section{LIMESTONES}

Description. Limestones from the Grajaú area are less abundant and less variable than those from the Codó area, occurring interbedded with argillites (Fig. 5) and only very rarely forming thin layers within the evaporite deposits. They occur as layers that are in general less than $20 \mathrm{~cm}$ thick, consisting of four facies: 1. massive mudstone (facies $\mathrm{Mm}$ ); 2. laminated mudstone-packstone (facies MPl); 3 . tufa (facies T); 4. stromatolitic, laminated boundstone (facies Bls); and 5. breccia (facies B).

Facies Mm is far the dominant one and represented mostly by gray massive mudstones. These deposits form layers up to $3-5 \mathrm{~cm}$ thick that are lat- erally continuous throughout the extension of the outcrops. At one place (i.e., locality 1 in Fig. 1), this facies occurs as discoidal concretions that are $10-15 \mathrm{~cm}$ long and less than 3-5 cm thick.

Facies MPl consists of yellowish brown mudstones to packstones displaying parallel to slightly undulating lamination, as well as small (up to $10 \mathrm{~cm}$ wide and $<3 \mathrm{~cm}$ in height) symmetrical and asymmetrical ripple marks. Fenestrae are locally abundant in this facies. The packstones are composed by bioclasts (ostracods) and peloids. No rarely, these deposits are recrystallized, forming areas in the thin sections that are entirely represented by mosaics of calcite crystals circa $500 \mu \mathrm{m}$ in diameter and with saturated contacts. Laminae of fibrous calcite displaying vertically aligned crystals few $\mathrm{mm}$ long are locally present in this facies.

Facies T (Fig. 6) occurs only locally, being characterized by highly porous limestones where the framework is hold by either vertically interconnecting filaments or a web of microcavities composed by micritic calcite. Calcite grains and yellowish to reddish-colored clay cutans are encrusted in this framework. Tufas form discontinuous lenses or layers 2-3 cm thick observed at the top of evaporite successions, being associated with gypsarenites and fenestral limestones of facies Mpl.

Facies Bls (Fig. 7) consists of stromatolites that form convex up, domal-shaped features up to $30 \mathrm{~cm}$ wide and $15 \mathrm{~cm}$ high. Petrographically, this facies consists of undulating laminae of micrite defined by dark films of algal mats. This facies was found at one locality (i.e., locality 3 in Fig. 1), and is vertically succeeded by breccias (facies B). These are yellowish and composed by intraclasts of mudstones that are either in contact with each other, forming a closed framework, or occur disperse within a matrix of micrite. The intraclasts vary from few $\mathrm{mm}$ up to $5 \mathrm{~cm}$ and they are elongated and subrounded. Imbrication is locally observed.

Interpretation. The several facies described in the limestone group indicate deposition in low-energy, shallow subaqueous environment, distant from a significant terrigenous inflow and undergone to peri- 

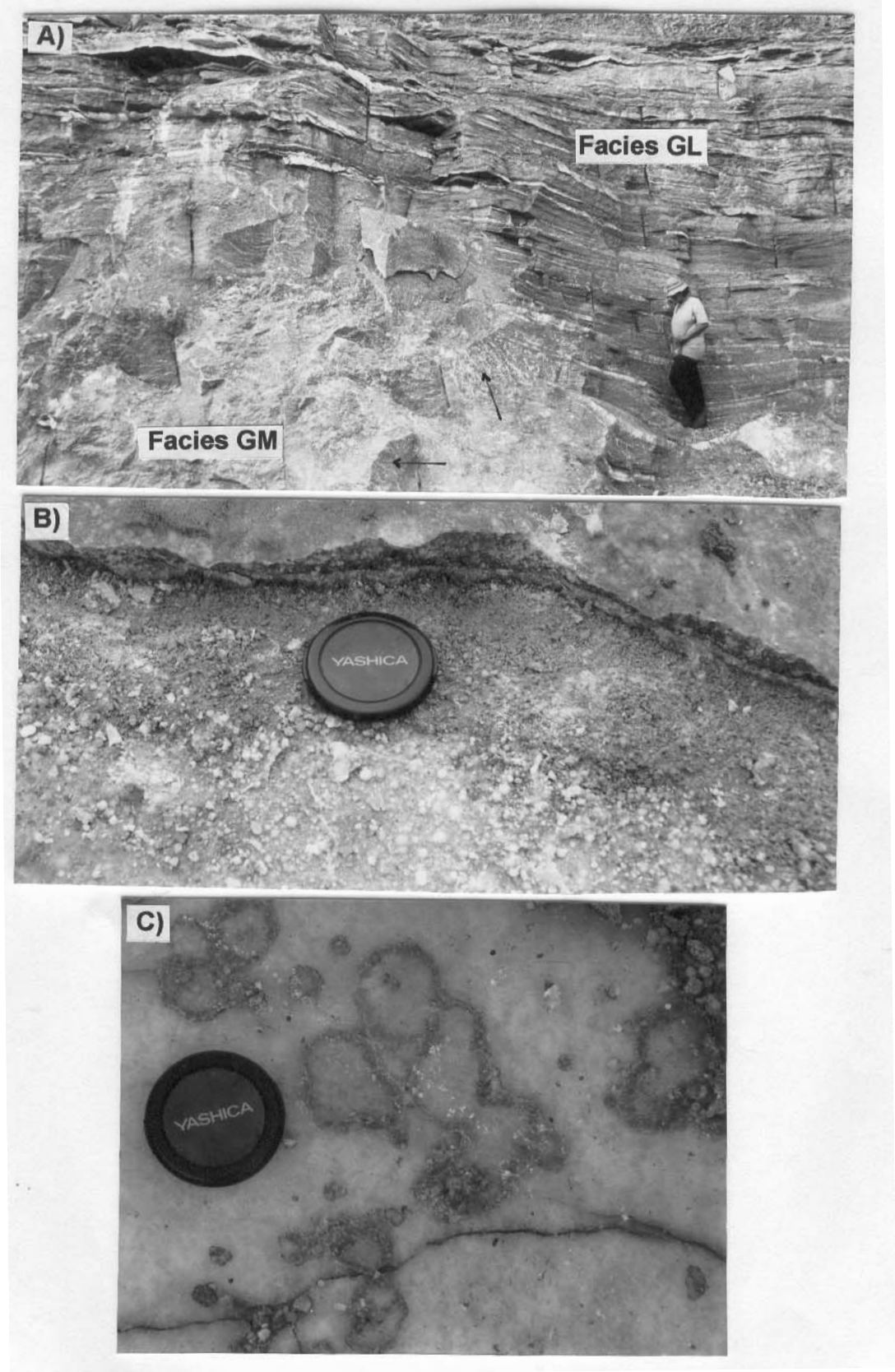

Fig. 4 - A) Massive gypsum (Facies Gm) forming a diapir that moved upward sharply disturbing the overlying laminated gypsum (facies $\mathrm{Gl}$ ). Note areas of laminated gypsum (arrows) still preserved within the massive gypsum. (Person for scale $=1.75 \mathrm{~m}$ tall). B) Gypsarenite facies (Gy) formed by reworked crystals of gypsum that form well-rounded grains. C) Pot hole structures (plan view), attesting local dissolution of the gypsum at the top of the evaporite succession. The dark colour surrounding the features corresponds to clay films that where deposited in the holes by suspension, just before they were completely filled up with gypsum crystals. (Lens cap for scale in $\mathrm{C}$ and $\mathrm{D}=10 \mathrm{~cm}$ in diameter). 


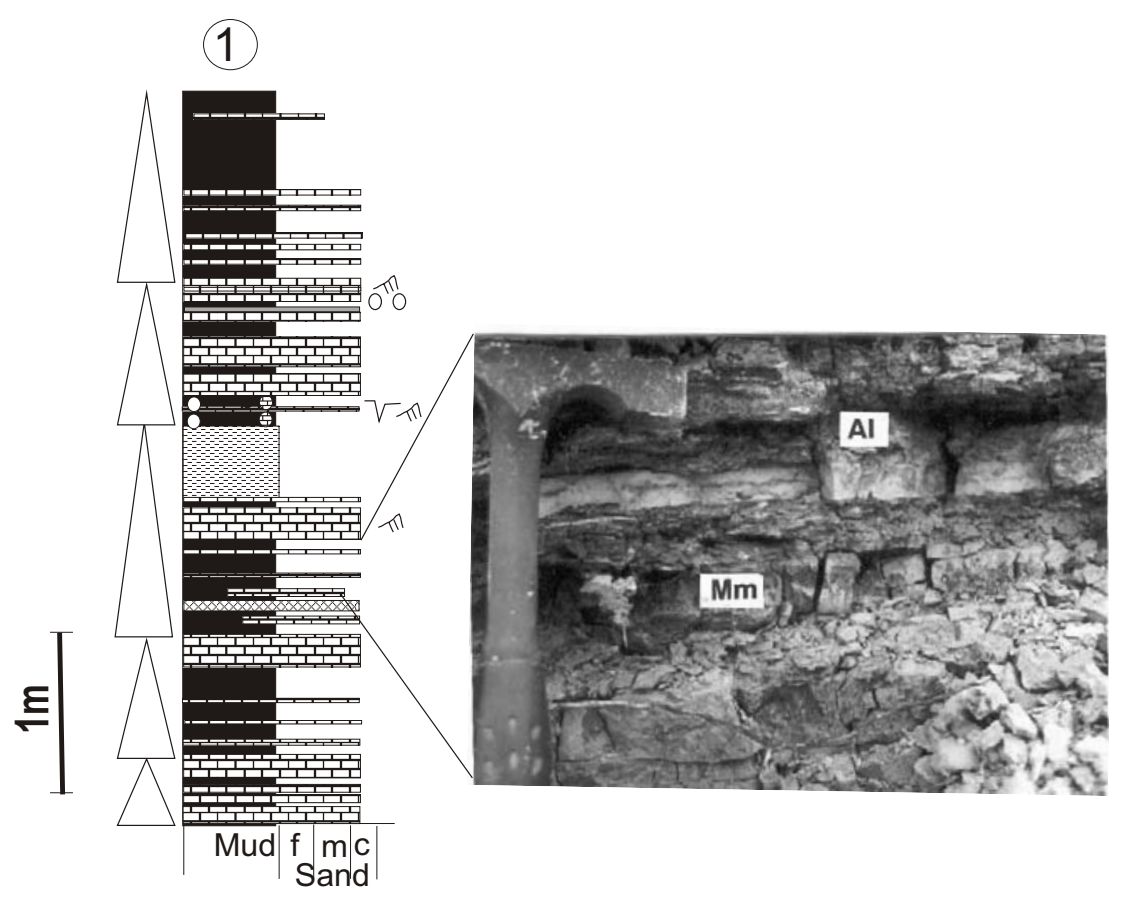

Fig. 5 - A lithostratigraphic profile recording thin layers of limestones interbedded with argillites (see photograph for detail, where $\mathrm{Mm}=$ mudstone and $\mathrm{Al}=$ laminated argillite), which are arranged into several shallowing-upward cycles (arrows) in a subaqueous environment with frequent exposure to meteoric and/or vadose conditions. (Hammer head for scale $=15 \mathrm{~cm}$ long). (See figure 2 for legend).

odic exposure. Low energy is particularly illustrated by the dominance of massive mudstones (facies Mm). Intermittent water agitation, possibly due to wave action, is suggested by the presence of wackestones-packstones with few ostracod shells, peloids and ripple marks. The fenestrae in this facies suggest deposition under meteoric and/or vadose influence.

The stromatolitic, laminated boundstones (facies Bls) attest to extensive in situ growth of microbial mats on bottom sediment. The dome shape is probably associated with the upward migration of gas bubbles produced by degradation of organic matter by sulfate reducing bacteria (Aref 1998). The formation of such type of stromatolites requires a more or less permanently subaqueous environment (Tucker 1978), but near the transition to subaerial conditions, as observed in modern settings
(Dean and Fouch 1983). A stable depositional setting is necessary for stromatolitic domes to develop (Tucker 1978), and the water salinity must be limited to less than $160 \mathrm{~g} / \mathrm{l}$ (Aref 1998).

Facies T records in situ organic growth, probably due to calcium carbonate precipitation around filaments of cyanobacteria developed under shallow subaqueous to subaerial conditions, as observed in modern (e.g., Cloud and Lajoie 1980) and ancient (Platt and Wright 1991, Riding 2000) settings. Clay cutans and calcite grains agglutinated in the framework are commonly observed in association with tufa deposits (Demicco and Hardie 1994, Eggleston and Dean 1976), being attributed to the passage of flows through the very porous framework, which bring sediment in suspension and also can partly cause mechanical reworking forming the calcite grains. The occurrence of tufa in the Grajaú 


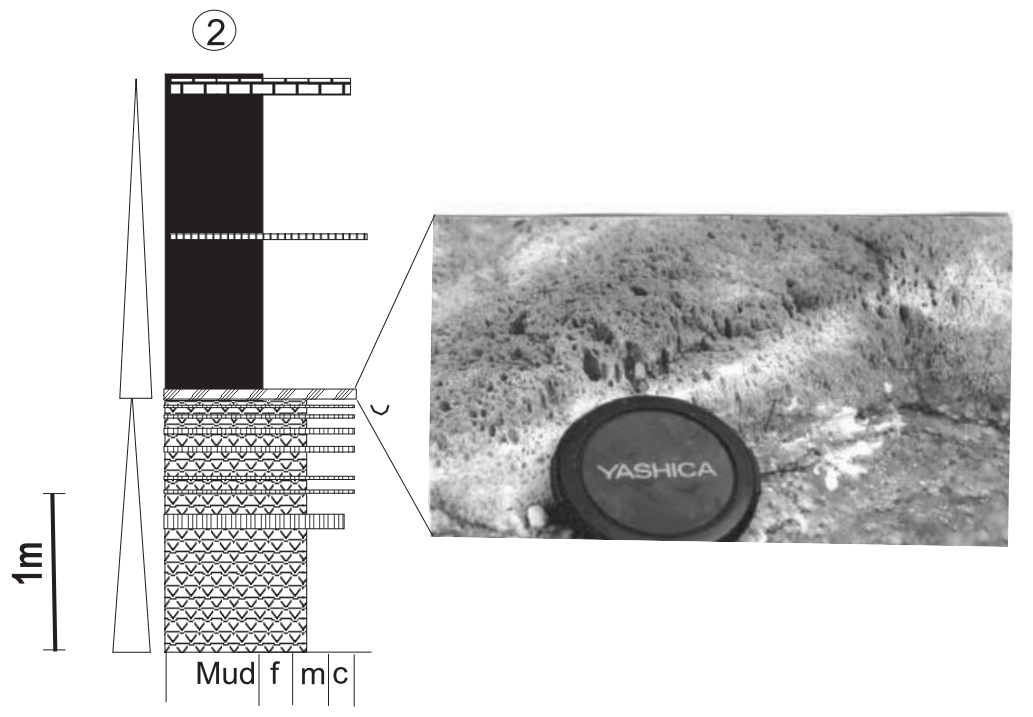

Fig. 6-A lithostratigraphic profile illustrating the top of an evaporite succession marked by dissolution structures (pot holes) and tufa (see photograph). Note that evaporites are overlain by argillite deposits (laminated argillite-facies $\mathrm{Al}$ ). (Lens cap for scale $=10 \mathrm{~cm}$ in diameter). (See figure 2 for legend).

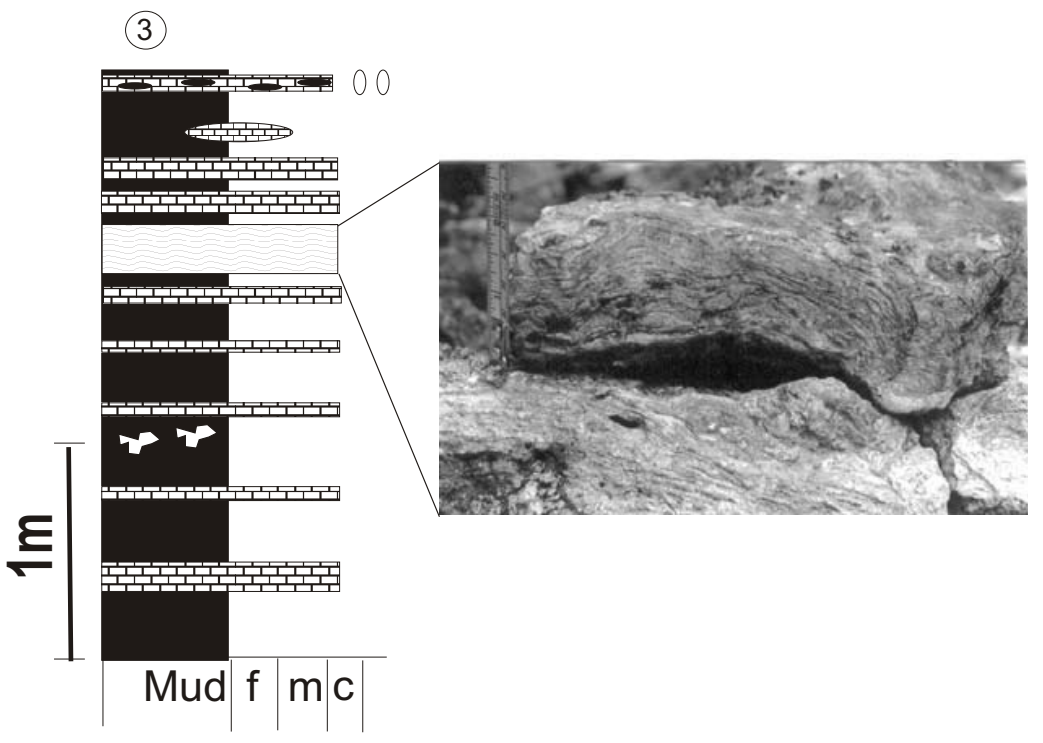

Fig. 7-A lithostratigraphic profile illustrating the position of stromatolite deposits (facies Bls, see photograph) within a succession of interbedded limestone and argillites. These were formed in a shallow subaqueous environment in marginal saline pans or lakes and mudflats. In addition to the stromatolites, this interpretation is suggested by the presence of fenestrae, tepee (indicated in the breccia horizon) and pop-corn structures. (Rule for scale is given in inches to the left and centimetre to the right). (See figure 2 for legend). 
area at the top of the evaporitic successions is taken as an evidence for subaerial exposure, marking a depositional time with maximum emergence.

Considering the proposed overall environment with intermittent subaerial exposure, the breccias characterized by intraformational mudstone clasts (facies B) probably resulted from local reworking of tepee structures. These formed from contraction and expansion of surface sediments through repeated desiccation and cement precipitation during extended periods of subaerial exposure. The formation of this facies in the study area is consistent with marginal vadose conditions (Tucker 1978, Demicco and Hardie 1994).

\section{Argillites}

Description. This lithological group is laterally continuous at the outcrop scale, being represented by laminated argillite (facies $\mathrm{Al}$ ), massive argillite (facies Am), and black shale (facies Sb). Facies Al, far the dominant one in this group, displays colors that vary from olive green to light gray, laminated argillite. These lithologies occur in two situations: laterally continuous deposits up to $4.5 \mathrm{~m}$ thick that occur either underlying or overlying evaporite beds (Fig. 2); and thin deposits less than $30 \mathrm{~cm}$ thick that are interbedded with limestones (Fig. 5). At some places (e.g., locality 3 in Fig. 1), lenses of nodular limestone forming structures like popcorn occur disperse in this facies.

Facies Am is up to $60 \mathrm{~cm}$ thick, being the second one in abundance within the argillite group. It is represented by slightly endurated deposits displaying a block texture, and colors that vary from olive gray to yellowish brown. This facies grades downward into structured deposits. Facies $\mathrm{Sb}$ is the least abundant, occurring locally at the base of evaporitic deposits. It consists of organically-rich bituminous, black shales with abundant algal matter. Packages of black shales are found incorporated within massive gypsum (facies $\mathrm{Gm}$ ).

Interpretation. The argillite group records deposition from suspension in low energy settings. The dominance of laterally continuous laminated argil- lites (Facies Al) supports mud settling in flat areas. The lack of interbedded coarser-grained terrigenous deposits indicates that the study area remained distant from flow runoffs. The presence of thin beds of laminated argillites alternated with limestone supports a setting with fluctuating input of suspended sediments, with mud and limestone being formed during wetter and drier periods, respectively. However, the thick packages of laminated argillites requires a relatively stable water body not undergone to exposures, as laminations are well preserved and do not show evidences of subaerial exposure. The black shales record less oxygenated, probably anoxic waters, when preservation of organic matter was favored. The restricted occurrence of this facies in the study area indicates that the water body kept oxygenated most of the time. The association of thicker laminated argillites with evaporite deposits indicates periods of relative basin deepening. The massive mudstones (Mm) are attributed to pedogenesis, based on the blocky appearance and gradation downward into structured deposits.

\section{DISCUSSION OF THE DEPOSITIONAL SETTING}

The sedimentary features preserved in all three lithological groups of the Codó Formation exposed in the Grajaú area attest the existence of a shallow, low energy setting with alternating periods of stable and ephemeral waters. Arid and hot climates favored evaporite precipitation. Facies succession is characterized by the upward gradation from subaqueously deposited, laminated argillites into evaporites that progressively show evidence for subaerial exposure, characterizing shallowing- and brining-up cycles. The dominance of such flooding-evaporative concentration-desiccation cycles suggests a saline pan complex as the most likely depositional setting. This type of environment occurs in shallow, low relief depressions formed by saline lakes or pans that are constantly dried and which is surrounded by mudflats (sabkhas).

Deciphering if the saline pan formed in a marine (marginal saline systems) or non-marine environment (playa systems) is not straightforward, as 
these settings display many features that are comparable (Hardie 1984, Lowenstein and Hardie 1985). In most cases, decision is made based on isotope composition of the evaporite minerals and nature of associated deposits. An ongoing ${ }^{87} \mathrm{Sr} /{ }^{86} \mathrm{Sr}$ isotope study carried out in the Grajaú area with basis on primary gipsite shows values (i.e., $0.708190 \pm 32$ to $0.708831 \pm 24$ ) that are more compatible with an inland area far from marine influence (Paz et al. 2003), considering that Upper Aptian marine waters worldwide presented much lower values, ranging from 0.70720 to 0.70735 (Burke et al. 1982). On the other hand, this study revealed ${ }^{34} \mathrm{~S} /{ }^{32} \mathrm{~S}$ values (i.e, $15,29 \%$ to $17.89 \%$ (CDT) that are consistent with Upper Aptian marine-derived brines, which ranged from $13 \%$ to $16 \%$ (Claypool et al. 1980). Thus, the $\mathrm{S}$ isotope data alone do not let to completely rule out a coastal location for the saline pan complex, but it is well-known that ${ }^{34} \mathrm{~S} /{ }^{32} \mathrm{~S}$ ratio is less sensitive as a brine source proxy indicator (e.g., Denison et al. 1998, Chivas et al. 1991, Playà et al. 2000). Therefore, together with the Sr isotope data, which is considered more reliable for paleoenvironmental interpretation, the nature of the deposits associated with the evaporites in the Grajaú area, in some aspects seems to favor the hypothesis of an inland saline pan complex. Fossils are rare in the argillites and limestones, and when present, they exclusively include ostracods similar to the freshwater ostracods recovered from the Codó area (Paz and Rossetti 2001). If marine influence was significant during deposition, at least a small assemblage of tolerant organisms such as gastropods and foraminifera would be expected. In addition, the limestones are composed exclusively of calcite, as occurs throughout the Codó area. If a coastal setting is to be considered, then magnesite and/or dolomite should be present, as recorded in most limestone-bearing modern and ancient coastal settings (Schreiber 1988, Handford 1990, Beninson and Goldstein 2001). Taking these into account, it can be stated that the Codó Formation exposed in the Grajaú area does not show any solid evidence of a marine shoreline, suggesting that deposition might have occurred under a dominantly continental influence. If a marine connection was in effect, evidences to demonstrate that remains to be documented.

The thick argillites associated with the evaporites were formed in a setting protected from subaerial exposure, and probably correspond to deposition in inner portions of the saline pan. Good water oxygenation dominated, and evaporite crystals, if formed in the water surface, were dissolved through the water column before reaching the bottom. These deposits grade upward into evaporites progressively displaying evidences for strandline deposition by ephemeral waters, suggesting that they were preferentially formed in marginal areas of the saline pan, as well as in mud flats. The argillite and limestone interbeddings record subaqueous deposition in shallow waters with periodic exposure, probably recording episodes of freshening. Decrease in water salinity favored formation of limestones instead of evaporites. There are many ancient models of saline pans, with or without evaporites, which resemble in several aspects the one proposed here (e.g., Fischer and Roberts 1991, Southgate et al. 1989, Simpson and Eriksson 1993, Talbot et al. 1994).

If interpretations are correct, then deposition of the evaporites from Grajaú differed slightly from those in the Codó area. There, evaporites occur at the base of shallowing-upward cycles, reflecting preferential deposition in central areas of a stratified saline lake during anoxic episodes (Paz and Rossetti 2001). Conversely, the evaporite deposits in the Grajaú area occur at the top of shallowing-upward successions, with deposition taking place mostly in marginal environments surrounding a fairly well oxygenated saline lake (though with local anoxia, when black shales were formed), representing moments when the water table was shallow with intermittent exposure of the sediments to phreatic and/or vadose capillarity evaporite precipitation.

If continental in origin, the source for the salt is not a problem in the Grajaú area, as the basin is surrounded by volcanic rocks. For instance, the Dead Sea derives most of the salts from volcanic rocks eroded by the Jordan River (Borchet and Muir 
1964). In the case of the Grajaú area, erosion of sedimentary rocks of the Parnaíba Basin, some including older evaporites, might have provided additional source for the evaporites. However, future studies must be conducted in order to better demonstrate the continental origin for the brines and determine their sources.

\section{CONCLUSIONS}

Some conclusions can be drawn from the facies analysis of the Codó Formation in the Grajaú area, which include:

1. The deposits were dominantly formed in a subaqueous, shallow, low energy setting undergone to alternating periods of stable and ephemeral waters. The depositional system is better interpreted as one represented by a saline pan complex formed by a central saline lake or pan surrounded by mudflats (sabkhas);

2. The depositional system was more probably located far from the influence of marine waters, unless one considers that the Equatorial Atlantic Ocean during the Late Aptian differed chemically from other oceans worldwide;

3. Although displaying similar lithologies, a comparison of the sedimentary features and facies architecture between the Grajaú and Codó areas revealed some basic differences in their depositional systems. Hence, the Codó area displays deposits formed in comparatively more stable, well-stratified lakes with significant periods of anoxia and closure, when evaporites where formed almost exclusively in deeper, central areas. Much more ephemeral conditions prevailed in the Grajaú area, with better-oxygenated water pans having evaporite precipitation only in their margins and along the surrounding mudflats;

4. The above-mentioned differences in depositional conditions might have been crucial to control the distribution of the evaporite deposits. Saline pan complexes display more widespread marginal pan and mudflats, the first been restricted to more depressed areas of the system. Since salt precipitation in the Grajaú area occurred preferentially along marginal pan and mudflats, the evaporite deposits are abundant and laterally continuous. Conversely, the evaporites in the Codó area occur only locally and as discontinuous lenses formed by highly saturated brines in central areas of locally developed pans or lakes.

\section{ACKNOWLEDGMENTS}

This project was supported by Conselho Nacional de Desenvolvimento Científico e Tecnológico CNPq (Project \#460252/01). The authors thank the student Eberton Lobato Rodrigues for thin section preparation.

\section{RESUMO}

Descrições faciológicas da Formação Codó na área de Grajaú são fornecidas pela primeira vez e suas características sedimentares comparadas àquelas da área de Codó, objetivando a reconstrução paleoambiental. Os depósitos da área de Grajaú incluem evaporitos, calcários e argilitos contendo feições indicativas de ambiente raso, salino, subaquoso, de baixa energia, e exposto a condições meteóricas e/ou capilares. Ciclos de inundação-concentração evaporítica-dissecação sugerem complexo salino rodeado por planícies evaporíticas de lama. A localização do sistema, se costeiro ou continental, é aberto a debate. Entretanto, a última hipótese é favorecida considerando-se: 1. dados isotópicos de $\mathrm{Sr}$ com valores mais elevados que aqueles esperados para águas marinhas do Neoaptiano; 2. composição calcítica dos calcários (ao invés de dolomítica e/ou magnesiana, como esperado em ambientes costeiros); e 3. presença de ostracodes continentais e ausência de fauna marinha. Essa interpretação é consistente com aquela proposta para os depósitos aptiano superior da área de Codó, onde o sistema deposicional caracterizou-se por águas anóxicas, bem estratificadas e mais estáveis, com precipitação evaporítica em áreas lacustres centrais. Já na área de Grajaú as depressões salinas foram mais oxigenadas e temporárias, com precipitação de sais em áreas marginais ou ao longo de planícies de lama adjacentes.

Palavras-chave: evaporito, reconstrução paleoambiental, lacustre, Neoaptiano, análise faciológica, Bacia de São Luís-Grajaú. 


\section{REFERENCES}

Aguiar GA. 1971. Revisão geológica da Bacia Paleozóica do Maranhão. In: Congresso Brasileiro de Geologia, 25, São Paulo. Anais..., São Paulo: SBG, 1971, 1: 113-122.

AREF MAM. 1998. Holocene stromatolites and microbial laminites associated with lenticular gypsum in a marine-dominated environment, Ras El Shetan Ara, Gulf of Aqaba, Egypt. Sedimentology 45: 245-262.

Azevedo RP. 1991. Tectonic evolution of Brazilian Equatorial Continental Margin Basins. London, 455p. (Doctorate Thesis. University of London).

BatısTa AM. 1992. Caracterização paleoambiental dos sedimentos Codó-Grajaú, Bacia de São Luís (MA). Belém, 102p. (M.Sc. Thesis. Universidade Federal do Pará).

Beninson KC And Goldstein RH. 2001. Evaporites and siliciclastics of the Permian Nippewalla Group of Kansas, USA: a case for non-marine deposition in saline lakes and saline pans. Sedimentology 48: 165-188.

Borchet H AND Muir RO. 1964. Salt deposits. The origin, metamorphism and deformation of evaporites, London: D. Van Nostrand Company Ltd, 338p.

Burke WH, Denison RE, Hetherington EA, KoepNICK RB, Nelson HF and Otto JB. 1982. Variation of seawater ${ }^{87} \mathrm{Sr} /{ }^{86} \mathrm{Sr}$ throughout Phanerozoic time. Geology 10: 516-519.

Chivas AR, Andrew AS, Lyons WB, Bird MI AND Donelly TH. 1991. Isotopic constraints on the origin of salts in Australian playas. 1. Sulphur Palaeogeog Palaeoclim Palaeoecol 84: 309-332.

Claypool Ge, Holser WT, Kaplan IR, SaKai H and ZAK I. 1980. The age curves of sulfur and oxigen isotopes in marine sulphates and their mutual interpretation. Chem Geol 28: 199-260.

Cloud P and Lajoie KR. 1980. Calcite impregnated defluidization structures in littoral sands of Mono Lake, California. Science 210: 1009-1012.

Dean WE and Fouch TD. 1983. Lacustrine environment. In: Scholle PA, Bebout DG and Moore CH. (Eds.), Carbonate depositional environments. AAPG, Memoir 33: 98-130.

Demicco RV and Hardie LA. 1994. Sedimentary structures and early diagenetic features of shallow marine carbonate deposits. SEPM, Atlas Series 1, 265p.
Denison RE, KiRKLANd DW And Evans R. 1998. Using strontium isotopes to determine the age and origin of gypsum and anhydrite beds. J Geol 106: 1-17.

EgGLEston JR AND DeAn WE. 1976. Freshwater stromatolitic bioherms in Green Lake, New York. In: WALTER MR. (Ed.), Stromatolites. New York: Elsevier, Developments in Sedimentology 20: 479-488.

Fischer WL ANd Roberts LT. 1991. Cyclicity in the Green River Formation (lacustrine Eocene) of Wyoming. J Sed Petrol 61: 1146-1154.

GóEs AM And Rossetti DF. 2001. Gênese da Bacia de São Luís-Grajaú, Meio-Norte do Brasil. In: RosSetti DF, Góes AM and Truckenbrodt W. (Eds.), O Cretáceo na Bacia de São Luís-Grajaú, Belém: Museu Paraense Emílio Goeldi, Coleção Friedrich Katzer, p.15-29.

HANDFORD CR. 1990. Halite depositional facies in a solar salt pond: a key to interpreting physical energy and water depth in ancient deposits? Geol 18: 691-694.

HANDFORD CR. 1991. Marginal marine halite: sabkhas and Salinas. In: Melvin JL. (Ed.) Evaporites, petroleum and mineral resources. Elsevier Developments in Sedimentology 50: 1-66.

HARDIE LA. 1984. Evaporites: marine or nonmarine? Am J Sci 284: 193-240.

Hovorka SD. 1987. Depositional environments of marine-dominated bedded balite, Permian San Andres Formation, Texas. Sedimentology 34: 1029-1054.

KeRr SD AND Thomson A. 1963. Origin of nodular and bedded anhydrite in Permian shelf sediments, Texas and New Mexico. AAPG Bull 47: 1726-1732.

Lima EA And Leite JF. 1978. Projeto estudo global de recursos minerais da Bacia do Parnaíba: integração geológica-metalogenética. DNPM/CPRM, Recife, v. 16.

Lima MR. 1982. Palinologia da Formação Codó na região de Codó, Maranhão. Boletim do Instituto de Geociências da Universidade Estadual de São Paulo 13: 116-128.

Logan BW. 1987. The MacLeod evaporite basin, western Australia. A.A.P.G. Memoir 44, 140p.

LowensteIn TK AND HARDIE LA. 1985. Criteria for the recognition of salt-pan evaporites. Sedimentology 32: 627-644. 
MeSNER JC AND WoOLdRIDGe LCP. 1964. Maranhão Paleozoic basin and Cretaceous coastal basins, north Brazil. Bull Am Assoc Petrol Geol 48: 1475-1512.

Paz JDS And Rossetti DF. 2001. Reconstrução paleoambiental da Formação Codó (Aptiano), borda leste da Bacia do Grajaú, MA. In: RossetTi DF, Góes AM AND Truckenbrodt W. (Eds.), O Cretáceo na Bacia de São Luís-Grajaú, Belém: Museu Paraense Emílio Goeldi, Coleção Friedrich Katzer, p. 77-100.

Paz JDS, Rossetti DF and Macambira MJB. 2003. Genesis of Late Aptian evaporites (Codó Formation), northern Brazil: facies and isotopic analysis of $\mathrm{Sr}$ and S. In: Latin American Congress of SedimenTOLOGY, 3, Belém. Abstract Book..., Belém, 2003, p. $137-140$

Platt NH and Wright VP. 1991. Lacustrine carbonates: facies models, facies distribution and hydrocarbon aspects. In: ANADÓN P, CABRERA LL AND Kelts K. (Eds.), Lacustrine Facies Analysis, Int Ass Sediment Spec Publ 13: 57-74.

Playà E, Ortí F and Rosell L. 2000. Marine to nonmarine sedimentation in the upper Miocene evaporites of the Eastern Betics, SE Spain: sedimentological and geochemical evidence. Sed Geol 133: 135-166.

REZENDE OM AND PAMPLONA HRP. 1970. Estudo do desenvolvimento do Arco Ferrer-Urbano Santos. Boletim Técnico da Petrobras 13: 5-14.

RIDING R. 2000. Microbial carbonates: the geological record of calcified bacterial-algal mats and biofilms. Sedimentology 47: 179-214.

Rossetti DF. 2001. Arquitetura deposicional da Bacia de São Luís-Grajaú. In: Rossetti DF, GóEs AM AND Truckenbrodt W. (Eds.), O Cretáceo na Bacia de São Luís-Grajaú, Belém: Museu Paraense Emílio Goeldi, Coleção Friedrich Katzer, p. 31-46.

Rossetti DF And Goes AM. 2004. Caracterização paleoambiental de depósitos albianos na borda sul da Bacia de São Luís-Grajaú: modelo de delta fluvial influenciado por tempestades. Rev Bras Geocienc (in press).

Rossetti DF AND Truckenbrodt W. 1997. Revisão estratigráfica para os depósitos do Albiano-Terciário (?) na Bacia de São Luís, Maranhão. Boletim do Museu Paraense Emílio Goeldi, Série Ciências da Terra 9: 31-43.
Rossetti DF, Paz JDS, Góes AM and Macambira M. 2000. A marine versus non-marine origin for the Aptian-Albian evaporites of the São Luís and Grajaú basins, Maranhão State (Brazil) based on sequential analysis. Rev Bras Geocienc 30: 642-645.

Rossetti DF, Góes AM and Arai M. 2001. A passagem Aptiano-Albiano na Bacia de São Luís-Grajaú, MA. In: Rossetti DF, Góes AM ANd Truckenbrodt W. (Eds.), O Cretáceo na Bacia de São Luís-Grajaú, Belém: Museu Paraense Emílio Goeldi, Coleção Friedrich Katzer, p. 101-117.

SCHREIBER BC. 1988. Subaqueous evaporite deposition. In: Schreiber BC. (Ed.), Evaporites and Hydrocarbons, New York: Columbia University Press, p. $183-255$.

Simpson EL AND ERIKsson KA. 1993. Thin eolinites interbedded within a fluvial and marine succession: early Proterozoic Whitworth Formation, Mount Isa Inlier, Australian Sed Geol 70: 39-62.

SMoot JP AND Lowenstein TK. 1991, Depositional environments of non-marine evaporites. In: MELviN JL. (Ed.), Evaporites, petroleum and mineral resources, Amsterdam: Elsevier, p. 189-347.

Southgate PN, Lambert IB, Donnelly TH, Henry R, Etminan H and Weste G. 1989. Depositional environments and diagenesis in Lake Parakeelya: a Cambrian alkaline playa from the Officer Basin, South Australia. Sedimentology 36: 1091-1112.

Talbot MR, Hom K and Williams MAJ. 1994. Sedimentation in low-gradient desert margin systems: a comparison of the Later Triassic of Northwest Somerset (England) and the later Quaternary of east-central Australia. In: Rosen MR. (Ed.), Paleoclimate and basin evolution of Playa Systems, Geological Society of America Special Paper, p. 97-117.

Tucker M. 1978. Triassic lacustrine sediments from South Wales: shore-zone clastics, evaporites and carbonates. Spec Publ Int Ass Sediment 2: 205-224.

WARren J. 1999. Evaporites: Their Evolution and Economics. Oxford: Blackwell Science, 438p. 